\author{
Abstracta Iranica \\ Abstracta Iranica Revue bibliographique pour le domaine irano-aryen \\ Volume 32-33 | 2013 \\ Comptes rendus des publications de 2009-2010
}

\title{
Patrik Hagman. The Asceticism of Isaac of Nineveh
}

\section{Florence Jullien}

\section{OpenEdition}

Journals

Édition électronique

URL : http://journals.openedition.org/abstractairanica/40829

DOI : 10.4000/abstractairanica.40829

ISSN : 1961-960X

Éditeur :

CNRS (UMR 7528 Mondes iraniens et indiens), Éditions de l'IFRI

Édition imprimée

Date de publication : 1 décembre 2013

ISSN : 0240-8910

\section{Référence électronique}

Florence Jullien, « Patrik Hagman. The Asceticism of Isaac of Nineveh », Abstracta Iranica [En ligne], Volume 32-33 | 2013, document 323, mis en ligne le 01 juillet 2016, consulté le 26 septembre 2020. URL : http://journals.openedition.org/abstractairanica/40829; DOI : https://doi.org/10.4000/ abstractairanica.40829

Ce document a été généré automatiquement le 26 septembre 2020.

Tous droits réservés 


\title{
Patrik Hagman. The Asceticism of Isaac of Nineveh
}

\author{
Florence Jullien
}

\section{RÉFÉRENCE}

Patrik Hagman. The Asceticism of Isaac of Nineveh. Oxford, Oxford University Press, 2010, 264 p. (Oxford Early Christian Studies.

1 Cette étude importante est consacrée à l'un des auteurs spirituels les plus populaires en milieu syriaque (VII s.), dont l'influence dépassa largement le monde iranien. Dix parties composent l'ouvrage, certaines étant thématiques (perception du "monde", conception de la crainte religieuse, pratiques ascétiques, eschatologie). Dans la dernière sont réunies les principales études sur Isaac et le corpus de ses œuvres, ainsi que la littérature secondaire.

\section{AUTEURS}

\section{FLORENCE JULLIEN}

EPHE, Paris 